\title{
Practice and Analysis of Space Service in Higher Vocational College Library-A Case Study
}

\author{
Qianqian Si \\ Library, Shanghai Civil Aviation College, Shanghai, China \\ Email:3200056732@qq.com
}

How to cite this paper: Si, Q.Q. (2019) Practice and Analysis of Space Service in Higher Vocational College Library-A Case Study. Open Access Library Journal, 6: e5965.

https://doi.org/10.4236/oalib.1105965

Received: November 28, 2019

Accepted: December 22, 2019

Published: December 25, 2019

Copyright $\odot 2019$ by author(s) and Open Access Library Inc.

This work is licensed under the Creative Commons Attribution International License (CC BY 4.0).

http://creativecommons.org/licenses/by/4.0/

\begin{abstract}
Taking the library of Shanghai Civil Aviation College as an example, this paper analyzes its space service practice, and finds that there are some problems in the space service of higher vocational college library: insufficient new space area, backward space service facilities, insufficient understanding of space service by librarians, and insufficient space service evaluation mechanism. Based on this, this paper puts forward the countermeasures of library space service in higher vocational colleges and provides reference for other higher vocational colleges to develop space service.
\end{abstract}

\section{Subject Areas \\ Education, Sociology}

\section{Keywords}

Higher Vocational College, Space Service, Space Type, Space Reconstruction

\section{Introduction}

In the 2019 Chinese government work report, it was first mentioned that it is necessary to implement enrollment expansion in higher vocational colleges, which shows that the state attaches importance to higher vocational education. As an important part of general higher education, higher vocational colleges are designed to cultivate applied talents with certain theoretical knowledge and strong practical ability. The library of higher vocational colleges is the cultural base serving teaching and scientific research and it is the second class of students. Its development orientation and talent training objectives complement each other. However, with the development of the times, the contradiction between the traditional library and the times has become more and more obvious, 
and the library transformation is imperative. In recent years, space issues have become the focus of scholars. The concept of "space service" was put forward by International Federation of Library Associations and Institutions in 2009. Wu Jianzhong ranked "Space re-engineering" the third in his "Ten Hot Topics of Re-Discussion on Library Development" [1]. Professor Ke Ping pointed out that "space and resource are two hot spots in future library design" at the "Symposium on Library Space Reconstruction and Functional Re-engineering" held in December 2018. Thus, "Library Space Service" has been a hot topic in the field of library research under the transformation of libraries in the new century.

In the new era, the core of the talent training target of higher vocational education in China is "technical skill talents". The return of technical skill talents training is the biggest highlight of the current orientation of talent training in higher vocational education in China. The state has focused on the training of high vocational talents from high-skilled talents to skilled technical talents, opening a new direction for the current talent training target [2]. Under the new situation, confronting these questions: how to create new space for the cultivation of applied technical talents, how to innovate service mode, how to meet the needs of talent development and attract readers, higher vocational colleges library should actively explore space service is an effective way. Taking the library of Shanghai Civil Aviation College as an example, this paper probes into its space service practice, hoping to provide reference for other libraries of higher vocational colleges to develop space service.

\section{Status of the Library of Shanghai Civil Aviation College}

The library of Shanghai Civil Aviation College is divided into Xuhui campus library and Pudong campus library. Xuhui campus library was put into use in 2014 , with a building area of 4236 square meters and a total of 618 reading seats. Pudong campus library officially opened in October 2018, with a building area of 3363 square meters and a total of 818 reading seats. The library space consists of borrowing room, reading room, civil aviation reference room, electronic reading room, self-study room and compact stacks. Picture 1 and Picture 2 are the photos of our two campus libraries.

\section{Practice of Space Service in the Library of Shanghai Civil Aviation College}

There is no consistent definition of "space service". Xiao Long of Peking University believes that differing from traditional library featured by collecting books and related services around collecting books, the newly added space is only for service, such as creative space, learning space, communication space and leisure space aiming to provide readers with cultural places for study, research and communication. It can be considered as "space service" [3].

Based on Xiao Long's definition of space service, this paper analyzes the practice of space service in libraries of our two campuses from three aspects: space 


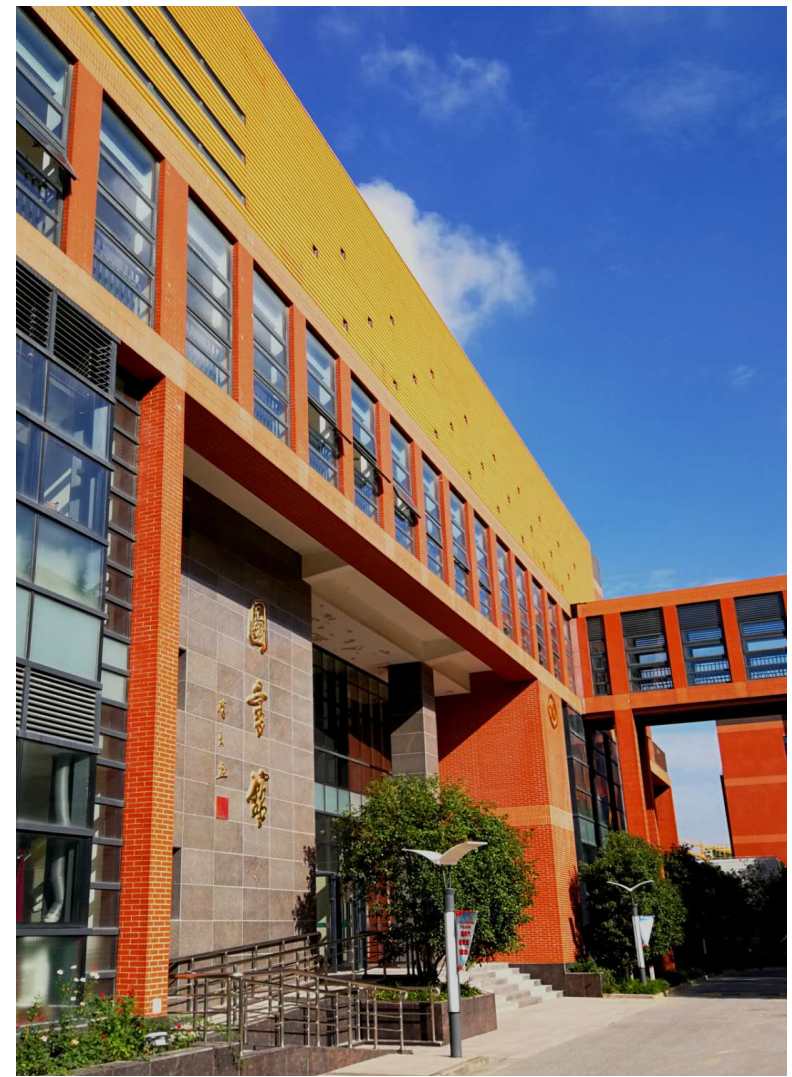

Picture 1. Xuhui campus library.

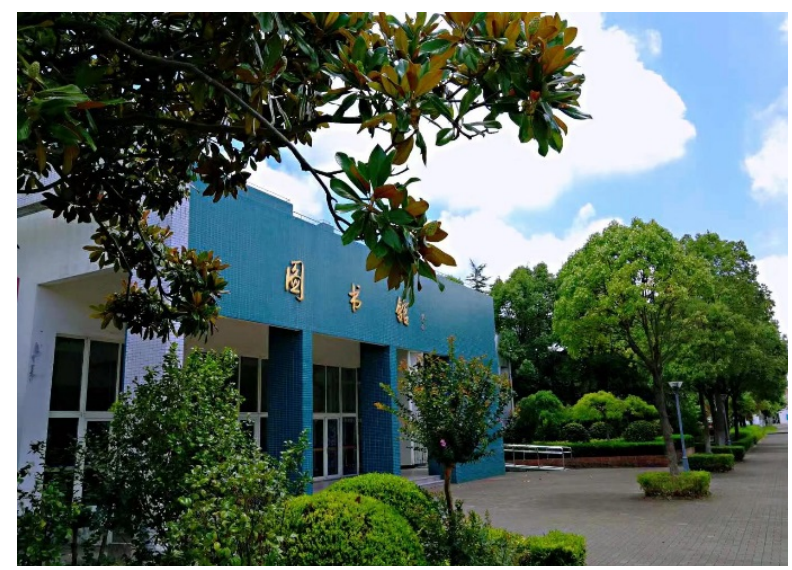

Picture 2. Pudong campus library.

type, space facilities and space service reconstruction.

\subsection{Space Type}

Based on the space function, the space type of our library can be divided into two categories: traditional library space and new library space. Different space functions, different service contents. According to the design of our library, the traditional space includes reading, borrowing and office areas, while the new space involves education space, entertainment \& display space as well as mobile 
service area.

\subsubsection{Traditional Library Space}

The space design of traditional libraries focuses on traditional service carriers (such as books, periodicals, newspapers, etc.) and the storage, lending and reading services take up a lot of space. The library of higher vocational college is a cultural institution for higher vocational students, which requires the library to provide physical space for reading and borrowing. The office area covers the basic functional departments of the library. It is a physical space for librarians to classify process, sort and store the collection resources, receive and serve readers' consultation. In terms of reading space, our library has a periodical reading room, mainly Chinese periodicals. The civil aviation reference room, located on the second floor of Xuhui campus library, provides Chinese and foreign civil aviation characteristic periodical literature. In terms of lending space, there is a lending room in each of our two libraries. In addition, in order to expand the reading space, Pudong campus library, together with the School Dormitory Management Office, set up a library in the students' living area, and provided some books and newspapers. In terms of office area, the office area of our two campus libraries is located on the second floor, the book and periodical processing area is located on the first floor, and the service desk is newly added on the first floor of Pudong campus library to provide readers with centralized services such as lending and returning, consultation, etc. Picture 3 and Picture 4 are the traditional library spaces.

\subsubsection{New Library Space}

Based on information technology and innovative service concept, the new library space, is a new type of library space, such as learning space, creative space, leisure space and experience space [4]. It is a new type of library space for traditional libraries and a positive extension of the concept of space creation.

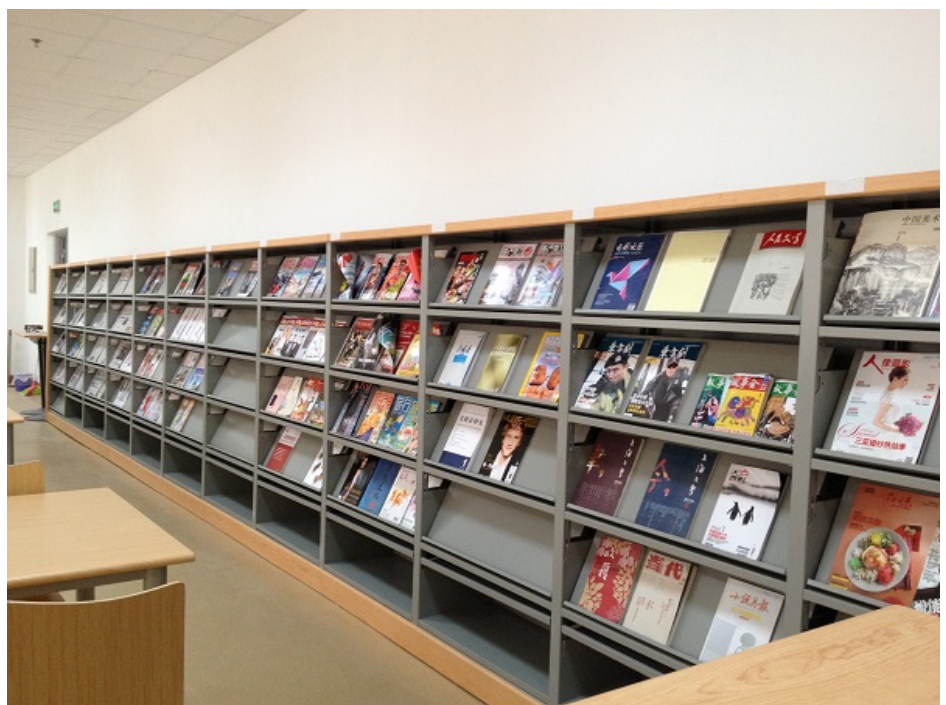

Picture 3. Xuhui campus periodical room. 


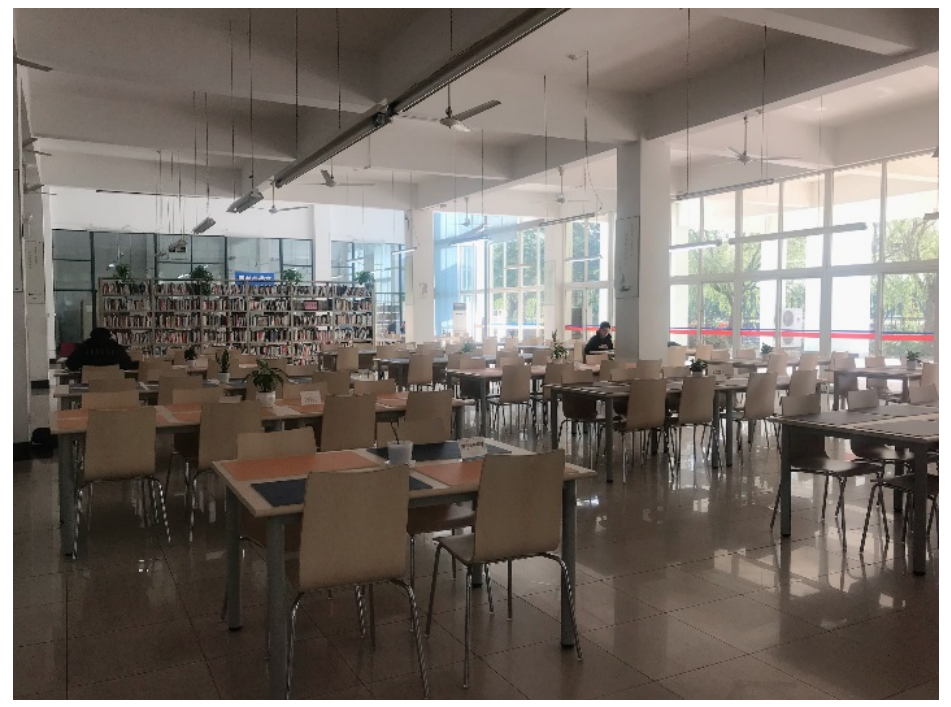

Picture 4. Pudong campus self-study area.

The new space of our library can be divided into education space, electronic reading area, mobile service space, exhibition space and entertainment space. Libraries in Picture 5 and Picture 6 respectively show the new library space.

1) Education space. The most important function of university library its educational function. Library is the base for college students to construct and update their professional knowledge. The scope of education space in this paper includes cultural space with educational function, such as lecture hall and training classroom. There are lecture halls in the library of our two campuses, information retrieval classrooms in both campus libraries, and reading rooms in the students' living areas in Pudong campus. Books and periodicals are updated regularly to facilitate students' reading.

2) Electronic reading area. The development of the internet has prompted libraries to use information technology and carriers to carry out digital resource access and mobile network information services in the library. The libraries of our two campuses have electronic reading areas and a certain number of computers. The first-floor hall is equipped with electronic newspapers and periodicals, Goethe e-books and other equipment.

3) Mobile service space. Our library provides mobile platform services in the form of WeChat subscription number, mobile library, Superstar Learning, etc. The service content includes library lending inquiry, library news trends, notice, resource retrieval, book recommendation, etc.

4) Exhibition space. Setting up exhibition area is an important way for college libraries to carry out cultural publicity and education. The libraries of our two campuses have set up exhibition areas on the ground floor for theme exhibitions. Take Pudong campus library as an example, librarians planned the "Chinese Civil Aviation History Exhibition" which is displayed in the two campus libraries to memorize the 70th anniversary of China Civil Aviation.

5) Entertainment space. Entertainment space is the third space created by the 


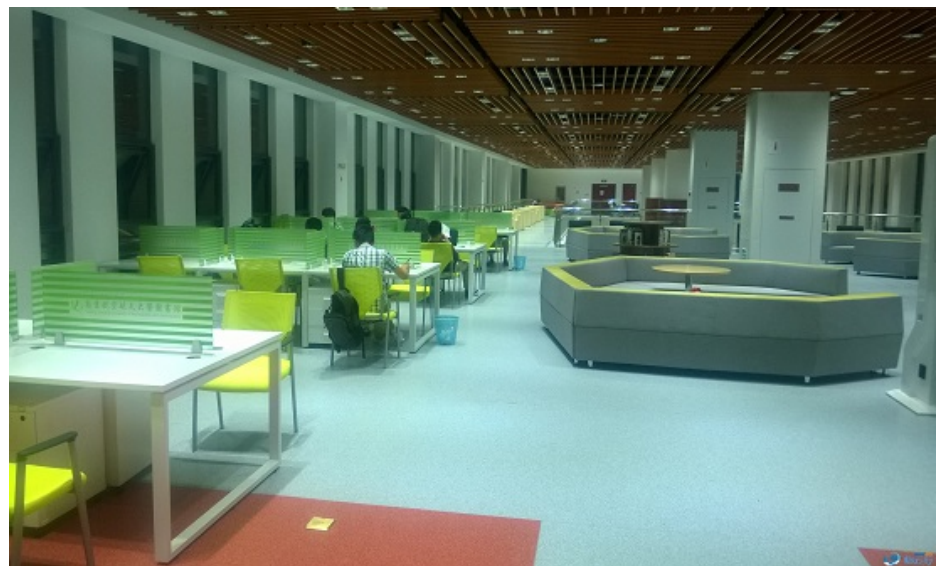

Picture 5. Library of Nanjing university of aeronautics and astronautics.

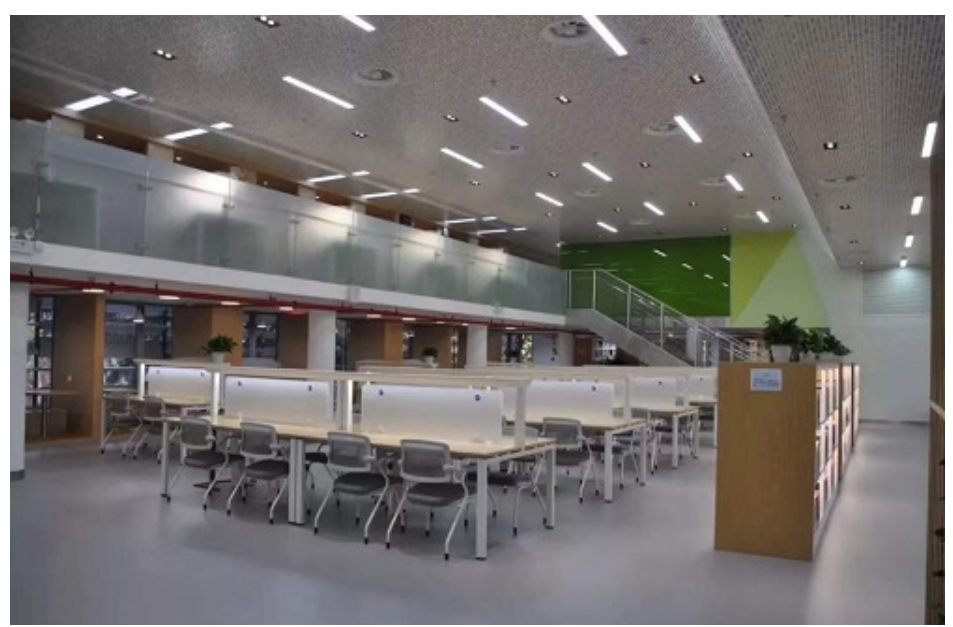

Picture 6. Library of Tongji University.

library for readers, and it is a space for readers to relax and entertain. Our library is actively exploring the construction of new types of space. The hall on the first floor of Xuhui campus library is equipped with leisure communication space. This area is relatively independent. Students can review all night during the exam. There is calligraphy corner, exhibition area, chess corner and table tennis table in the hall of Pudong campus library, providing leisure and exercise space for teachers and students.

\subsection{Construction of Space Service Facilities}

The space service facilities of university library provide guarantee for readers to make convenient use of library resources and help readers to better experience and make use of library resources from multiple perspectives.

\section{Self-Service Equipment}

The self-service of university library is a user self-service mode and a humanized service mode with a service concept of "reader oriented". It has a positive meaning for improving service efficiency, service quality, saving personnel costs, 
promoting readers' sense of participation and convenient service for readers, and it is the development direction of library service in the future.

In terms of self-service equipment, the types of space service facilities in our library include e-book readers, self-service newspapers and periodicals, touchscreen reading systems, self-printing and copying machines, self-service retrieval equipment and inquiry systems, self-service cameras, and self-service coffee machines. Our self-service newspapers and periodicals cover more than 30 kinds of electronic newspapers and 9000 kinds of electronic periodicals, and the e-book reader stores more than 6000 books. Readers can choose to read online as well as install mobile client to scan the periodical or book QR code for offline reading. Pudong campus library is equipped with a self-service printing copier. Readers can choose printing and copying functions as required. The libraries of the two campuses are equipped with self-service retrieval machines, and readers can search books and periodicals by inputting content such as title, responsible person, subject words, etc. In addition, the electronic reading rooms of the two campuses can also browse and download online digital resources by self-service.

\subsection{Space Service Reconstruction}

The library of our two campuses has undergone the space service reconstruction. The types of space reconstruction include idle space and functional reorganization space. For example, Pudong campus library integrates the service contents to create a comprehensive service desk on the first floor. In order to improve the space utilization rate, calligraphy corner, chess corner, exhibition area and table tennis room were added in the spare space on the first floor. In order to provide readers with a warm and comfortable reading environment, artificial flowers were placed in the self-study area and periodical reading area, and the use of reading table mat was adjusted according to the season. Xuhui campus library focused on the transformation of the civil aviation reference room, readjusting the layout of sofa chairs and reading tables, adding lamps, green plants, etc. The upgraded space is a shared space for learning, experience, entertainment and exchange. In addition, Xuhui campus library rearranged the hall on the first floor, adding exhibition area, electronic equipment service area, leisure and exchange area.

\section{Problems of Space Service in Higher Vocational Colleges}

1) New library space is insufficient. According to the survey on the type of library space in our college, $80 \%$ of the library space belongs to the traditional space, while the new space only accounts for about $20 \%$. The existing space has not yet reflected the characteristics of civil aviation and cannot meet the needs of readers for the new characteristic space.

2) The construction of space service facilities is backward. Due to the shortage of funds and improper management methods, the self-service equipment in the library of higher vocational colleges is relatively deficient in types and quantities. 
Currently, the two campuses respectively provide 8 retrieval machines in the library lending room and periodical room, which can basically meet the needs of readers' retrieval. However, with the expansion of our school's enrollment scale year by year, the two campuses should timely increase and update the retrieval equipment according to the changes in the number and demand of readers. There is a lack of clear self-service guidance instructions and usage instructions for the existing self-service equipment.

3) The librarians have insufficient understanding of space service. Most of the Librarians in higher vocational colleges are older, their knowledge structure is aging, they have fewer opportunities to go out for training and visit, and they have poor ability to learn new technology and knowledge. All of these will lead to the lack of adequate understanding of the new space service for the librarians, and it is difficult to change the traditional service model of the library, thus limiting the ability and service level of serving the readers.

4) There is a lack of space service evaluation mechanisms. Before the reconstruction of space service, the library of higher vocational college will ask for the readers' opinions and demands through various ways, but after the reconstruction, it does not investigate the readers' feelings and suggestions in time, which is not conducive to improving the readers' satisfaction. At present, there is not a unified evaluation standard of space service, which cannot effectively measure the quality and level of space service of libraries in vocational colleges.

\section{Development Strategy of Space Service in Higher Vocational Colleges}

1) Strengthen the cultivation of the overall quality of the librarians and improve the space service ability of the librarians. With the diversification of space service types and the expansion of service scope in higher vocational colleges, the new space service requires librarians not only to have professional information management technology knowledge, but also to master communication skills and psychological knowledge, actively communicate with readers, and continuously improve readers' satisfaction.

2) Actively build new space and highlight the characteristics of civil aviation. Our college trains many talents for civil aviation every year. The quality of talents is directly related to the future of civil aviation. As a talent breeding base, the library should do its best to build civil aviation characteristic service space, such as civil aviation history exhibition hall, civil aviation maker space, civil aviation exchange space, etc.

3) Strengthen the construction of space service facilities and rely on information technology to promote the development of space services. While improving the infrastructure construction, libraries of higher vocational colleges should increase the investment in information system and self-service equipment, improve the efficiency of space management, and provide readers with different experience. 
4) Strengthen cooperation with internal and external organizations to expand new space services. Libraries in higher vocational colleges should pay attention to the collaboration with internal and external institutions, actively explore innovative library space services, and use the resources of external forces to expand the library services to the readers.

5) Respect users' needs and develop an evaluation mechanism. In the process of planning space service, higher vocational college libraries should take full consideration of readers' needs and invite users to participate in the space service of libraries. Besides, the establishment of a reasonable evaluation mechanism can help the libraries of higher vocational colleges to fully understand the real feelings and thoughts of users after using the library, find the deficiencies in the space service process, and take measures to rectify in time.

\section{Conclusion}

Taking the library of Shanghai Civil Aviation College as an example, this paper analyzes its space service practice and finds that there are still some problems in the space service of the library of higher vocational college. In the information age, in order to provide users with satisfactory space services, the following aspects should be noted. First, library should strengthen the cultivation of the overall quality of librarians and improve their space service ability; second, library should actively build new space and highlight the characteristics of civil aviation; third, library should strengthen the construction of space service facilities and promote the development of space services based on information technology; fourth, library should strengthen cooperation with internal and external institutions to expand new space services; fifth, to respect the needs of users and formulate an evaluation mechanism. Since only one higher vocational college is selected as the research object in this paper, the characteristics and existing problems of space service in higher vocational colleges are not summarized comprehensively, so more samples need to be selected for further research in the future research.

\section{Conflicts of Interest}

The authors declare no conflicts of interest regarding the publication of this paper.

\section{References}

[1] Wu, J.Z. (2017) Re-Discussion of Ten Hot Topics in the Development of Librarianship. Journal of Library Science in China, 43, 4-17.

[2] Qiu, L., Zhao, L. and Guan, D.W. (2018) Re-Understanding and Thinking about the Positioning of the Talent Specifications and Training Objectives of Higher Vocational Education. Adult Education, 38, 73-77.

[3] Xiao, L. (2013) The Library Space Functionality and Spatial Layout Design in Post Digital Library Era. Library and Information Science, 57, 5-10.

[4] Zhao, Z.G. (2015) The Transformation and Development of New Library Space in the Information age. Library World, 4, 4-7+21. 